\title{
Manajemen Alokasi Bandwidth Layanan Internet Menggunakan Fractional Knapsack Problem
}

\author{
Bandwidth Allocation Management of Internet Services Using Fractional \\ Knapsack Problem
}

Ahmad Rizaqu Muttaqi, Sri Wahjuni*), Shelvie Nidya Neyman

Departemen Ilmu Komputer, Fakultas Matematika dan Ilmu Pengetahuan Alam, Institut Pertanian Bogor Jl. Meranti Wing 20 Level V, Kampus IPB Dramaga, Bogor, Indonesia 16680

Cara sitasi: A. R. Muttaqi, S. Wahjuni, and S. N. Neyman, "Manajemen Alokasi Bandwidth Layanan Internet Menggunakan Fractional Knapsack Problem," Jurnal Teknologi dan Sistem Komputer, vol. 7 no. 2, 2019. doi: 10.14710/jtsiskom.7.2.2019.71-76, [Online].

\begin{abstract}
The technical problems faced in egovernment implemented by the Ministry of Religion of Indonesia since 2015 are minimal bandwidth requirements to provide information services and behavior of users who access entertainment sites. When peak hours occur, the congested network often occurs which becomes a significant bottleneck. This study aims to implement bandwidth management using the fractional knapsack problem method by limiting access to entertainment services. The QoS parameters used in this management are throughput, delay, and jitter. The method was tested using a paired t-test using throughput, jitter, and delay test parameters by comparing test parameters before and after bandwidth management applied. The significance value produced is between $75-85 \%$. The method used can control the amount of traffic for each service, but on the other, hand the delay and jitter are still high. It is necessary to add additional free space to each service that can be used when needed to reduce the delay and jitter.
\end{abstract}

Keywords - bandwidth allocation; fractional knapsack problem;e-government services management

Abstrak - Kendala teknis lapangan yang dihadapi dalam layanan e-goverment oleh Kementerian Agama RI sejak tahun 2015, di antaranya adalah kebutuhan bandwidth minimal untuk menjalankan sistem informasi dan perilaku pengguna yang mengakses situs-situs yang bersifat hiburan. Saat terjadi jam-jam sibuk (peak hour) sering terjadi kepadatan jaringan yang menjadi bottleneck secara signifikan. Penelitian ini bertujuan mengkaji manajemen bandwidth menggunakan metode fractional knapsack problem dengan membatasi akses layanan yang bersifat hiburan. Parameter QoS yang digunakan dalam manajemen ini adalah throughput, delay, dan jitter. Metode tersebut diuji menggunakan uji t berpasangan

\footnotetext{
${ }^{*}$ Penulis korespondensi (Sri Wahjuni)

Email: my_juni04@yahoo.com
}

menggunakan parameter uji throughput, jitter, dan delay dengan membandingkan parameter uji sebelum dan sesudah dilakukan manajemen bandwidth. Nilai signifikansi yang dihasilkan adalah antara $75-85 \%$. Metode yang digunakan dapat mengendalikan jumlah trafik pada setiap layanan, namun di sisi lain nilai delay dan jitter masih tinggi. Untuk itu, perlu dilakukan penambahan free space alokasi pada setiap layanan yang dapat digunakan pada saat diperlukan agar dapat menurunkan nilai delay dan jitter.

Kata Kunci - alokasi bandwidth; fractional knapsack knapsack problem;manajemen layanan e-goverment

\section{Pendahuluan}

Pertengahan tahun 2015, Kementerian Agama RI meluncurkan beberapa layanan e-government di antaranya layanan Education Management Information System (EMIS), Sistem Pengelolaam Data Pendidik Dan Tenaga Kependidikan Kementerian Agama (SIMPATIKA), Sistem Informasi Pagu Anggaran (SIPA), Sistem Komputerisasi Haji Terpadu (SISKOHAT), dan Sistem Informasi Bimbingan Masyakat Islam (SIMBI). Dengan adanya pengembangan layanan e-government tersebut, perancangan manajemen jaringan komputer yang memadai diperlukan untuk mencapai kinerja maksimal.

Ada beberapa kendala yang dihadapi secara teknis pada jaringan komputer, di antaranya adalah kebutuhan minimal bandwidth untuk menjalankan sistem informasi, tidak tersedianya dokumentasi topologi jaringan yang terinstalasi, dan perilaku pengguna jaringan yang tidak mendukung kinerja, seperti mengakses situs-situs yang bersifat hiburan, misalnya jejaring sosial, layanan video streaming, game online, hingga layanan berbagi file (peer to peer). Saat terjadi jam-jam sibuk atau peak hour sering terjadi kepadatan jaringan atau bottleneck. Terlebih saat menjelang ibadah haji, akan terjadi lonjakan trafik jaringan secara signifikan. Untuk meningkatkan efisiensi dan efektivitas penggunaan internet dan intranet yang berhubungan dengan tugas-tugas kedinasan dan keperluan kantor di 
lingkungan Kementerian Agama, maka perlu dilakukan pengaturan dan limitasi penggunaan bandwidth terutama untuk akses ke jejaring media sosial yang membutuhkan bandwidth besar, seperti Youtube, Facebook, Twitter, streaming video/music, game online dan penggunaan aplikasi downloader [1].

Pelaksanaan manajemen bandwidth yang dilakukan administrator berdasarkan kondisi yang berjalan di lapangan saat ini hanya berdasarkan pengalaman atau perkiraan subjektif tanpa mempertimbangkan Quality of Service (QoS) sehingga menghasilkan manajemen bandwidth besifat kualitatif. QoS dibutuhkan untuk menyediakan layanan yang lebih baik dengan meminimalkan packet loss, delay, latency dan delay variation (jitter) [2]. Implementasi QoS pada jaringan untuk melakukan pengendalian trafik jaringan dengan melakukan manajemen bandwidth telah dilakukan dalam [3]-[5].

Manajemen bandwidth dilakukan untuk mengatasi terjadinya bottleneck pada jaringan, yaitu dengan cara mengklasifikasikan paket sebagai parameter prioritas menggunakan metode antrian (queue) dan penjadwalan (scedule) berdasarkan buffer pada paket dengan pendekatan matematis untuk mendapatkan ketersediaan bandwidth [3]. Metode lain yang digunakan dalam manajemen bandwidth adalah fractional knapsack problem untuk menyelesaikan permasalahan kebutuhan kecepatan data dan keterbatasan bandwidth [4], [5]. Proses penjadwalan sebagai solusi optimum dilakukan untuk membatasi overload pada jaringan. Nilai bobot pada fractional knapsack problem didasarkan pada rasio jumlah panjang antrian.

Berbeda dengan [3]-[5] yang belum memiliki pembagian atau pengalokasian bandwidth secara spesifik untuk setiap layanan yang diidentifikasi dan hanya berorientasi pada panjang antrian paket data, penelitian ini menerapkan manajemen bandwidth berbasis akses layanan e-government dengan pembatanan akses layanan yang bersifat hiburan. Layanan diidentifikasi berdasarkan prioritas dan proporsi bandwidth yang diperlukan. Pengalokasian bandwidth untuk tiap layanan dilakukan dengan menggunakan fractional knapsack problem dan diterapkan di lingkungan Kantor Kementerian Agama.

\section{Metode Penelitian}

Manajemen bandwidth dalam penelitian ini menggunakan metode knapsack problem untuk memberikan solusi persoalan optimasi dalam pemilihan objek, yaitu layanan, yang dapat dimasukkan ke dalam sebuah kapasitas yang memiliki keterbatasan daya tampung, yaitu jumlah bandwidth. Objek yang dimasukkan memiliki bobot dan nilai kentungan berbeda untuk menentukan prioritas dalam pemilihan objek sehingga diharapkan dapat menghasilkan keuntungan maksimum [6]. Pengalokasian bandwidth berdasarkan [1] dan layanan diklasifikasikan dalam kategori layanan seperti Tabel 1 .
Tabel 1. Klasifikasi layanan

\begin{tabular}{ll}
\hline Kategori & Layanan \\
\hline e-government & EMIS Pendis \\
Kementerian & SIMPATIKA Direktorat GTK \\
Agama & SIMBI BIMAS Islam \\
& SIMAS BIMAS Islam \\
& SIWAK BIMAS Islam \\
& SIMPENAIS Bimas Islam \\
& iwaris Kanwil Kemenag Jabar \\
& LPSE Kemenag SetJen \\
& E-MPA Kemenag \\
& Email Kementerian Agama \\
& Sistem Informasi Layanan \\
& Gangguan dan Permohonan \\
& (SIGAP) SetJen \\
& Dirjen PHU \\
& SIMPEG Kemenag Biro \\
& Kepegawaian Setjen \\
Pendukung & Google Service \\
e-government & \\
Media Sosial & Facebook \\
& Twitter \\
& Instagram \\
Lainnya & Game \\
& Tidak terklasifikasi \\
\hline
\end{tabular}

Tabel 2. Penentuan tingkat prioritas

\begin{tabular}{|c|c|c|c|}
\hline Layanan & $\begin{array}{c}\text { Tingkat } \\
\text { prioritas }\end{array}$ & $\begin{array}{c}\text { Nilai, } \\
v_{j i}\end{array}$ & $\begin{array}{c}\text { Proporsi } \\
\text { bandwidth setiap } \\
\text { prioritas, } x_{i}\end{array}$ \\
\hline $\begin{array}{l}\text { e-government } \\
\text { Kementerian } \\
\text { Agama }\end{array}$ & Tinggi & 3 & 0.6 \\
\hline $\begin{array}{l}\text { Pendukung e- } \\
\text { government }\end{array}$ & Sedang & 2 & 0.3 \\
\hline Media sosial & Rendah & 1 & 0.1 \\
\hline $\begin{array}{l}\text { Lainnya (tidak } \\
\text { terklasifikasikan) }\end{array}$ & Rendah & 1 & 0.1 \\
\hline
\end{tabular}

Penentuan tingkat prioritas layanan dilakukan berdasarkan tingkat kebutuhan setiap layanan. Tingkat prioritas diinisialisasikan menjadi 3, yaitu tingkatan tinggi, sedang, dan rendah. Hasil penentuan tingkatan prioritas, value, dan proporsi bandwidth ditunjukkan di Tabel 2. Penentuan tingkat prioritas tinggi dialokasikan untuk layanan e-government karena layanan internet prioritaskan untuk mengakses layanan yang ada di Kementerian Agama. Prioritas sedang dialokasikan untuk layanan pendukung e-government seperti layanan email dan cloud storage. Prioritas rendah dialokasikan untuk layanan media sosial yang bersifat hiburan dan tidak mendukung kinerja.

Setelah didapatkan klasifikasi dan tingkat prioritas layanan, dilakukan penyesuaian nilai bandwidth. Penentuan nilai alokasi bandwidth berdasarkan tingkat prioritas (tinggi, sedang, dan rendah) menggunakan 
Tabel 3. Parameter nilai fractional knapsack problem

\begin{tabular}{lcc}
\hline Prioritas & $\begin{array}{c}\text { Proporsi } \\
\text { bandwidth, } x_{i}\end{array}$ & $\begin{array}{c}\text { Alokasi bandwidth } \\
\text { kbps, } w_{i}\end{array}$ \\
\hline Tinggi & 0.6 & 3000 \\
Sedang & 0.3 & 1500 \\
Rendah & 0.1 & 500 \\
\hline
\end{tabular}

Persamaan 1, seperti pada [7]. Parameter $w_{i}$ menunjukkan alokasi bandwidth prioritas ke- $i, x_{i}$ prioritas bandwidth prioritas ke- $i$ dengan $0 \leqslant x_{i} \leqslant 1$, dan $W$ jumlah bandwidth (5000 kbps).

$$
w_{i}=x_{i} \times W
$$

Parameter nilai fractional knapsack problem ditunjukkan pada Tabel 3. Nilai tersebut digunakan untuk penyesuaian alokasi bandwidth tiap layanan yang dapat dihitung berdasarkan nilai konsumsi bandwidth $\left(c_{j i}\right)$, value $\left(v_{j i}\right)$ diperoleh dari tingkat prioritas pada Tabel 2, dan proporsi bandwidth tiap layanan $\left(r_{j i}\right)$. Nilai proporsi bandwidth tiap layanan dinyatakan dalam Persamaan 2. Parameter $r_{j i}$ menyatakan proporsi bandwidth layanan ke-j pada prioritas ke-i, $c_{j i}$ konsumsi bandwidth layanan ke-j pada prioritas ke-i, dan $c_{i}$ konsumsi bandwidth pada prioritas ke-i.

$$
r_{j i}=\frac{c_{j i}}{c_{i}}
$$

Nilai konsumsi bandwidth pada tiap tingkatan prioritas pada Persamaan 2 diperoleh dengan mengakumulasikan nilai konsumsi bandwidth setiap layanan pada tingkatan prioritas masing-masing seperti pada Tabel 3. Hasil Persamaan 2 dilakukan penghitungan alokasi bandwidth tiap layanan seperti dinyatakan dalam Persamaan 3. Parameter $w_{j i}$ menunjukkan alokasi bandwidth layanan ke-j pada prioritas ke-i, $r_{j i}$ proporsi bandwidth layanan ke-j pada prioritas ke-i, dan $w_{i}$ alokasi bandwidth prioritas ke-i.

$$
w_{j i}=r_{j i} \times w_{i}
$$

Hasil pembagian bandwidth diimplementasikan ke dalam pengaturan router Mikrotik menggunakan fitur firewall filter dan firewall mangle. Firewall filter untuk melakukan blok terhadap website berdasarkan alamat IP, port dan alamat url. Firewall mangle digunakan untuk menandai atau marking sebuah paket data. Implementasi firewall filter dan mangle menggunakan perintah Command Line Interface (CLI) [8].

Untuk menguji tingkat efektivitas dari manajemen bandwidth sebagai dasar evaluasi metode fractional knapsack problem, maka dilakukan uji beda menggunakan uji $t$ berpasangan dengan parameter uji yaitu bandwidth, jitter, dan delay [3] dan dioperasikan menggunakan [9]. Pengujian pertama membandingkan sebelum dan sesudah klasifikasi layanan berdasarkan alokasi yang diberikan. Pengujian kedua mengukur parameter uji setelah manajemen bandwidth diterapkan.

Kriteria pendekatan manajemen bandwidth dikatakan efektif jika memenuhi H1, $H_{1}=\mu_{x}-\mu_{y} \neq \Delta_{0}$, dengan nilai $P$-value pada area perpotongan antara $t$ dan -t, dengan nilai t-hitung $>$ t-table dan tingkat signifikansi $\geq 70 \%$ atau batas error $(\alpha) 30 \%$. Penentuan taraf signifikansi $70 \%$ didasarkan pada konsumsi bandwidth sebesar $30 \%$ dari jumlah bandwidth keseluruhan. Jika H1 ditolak, maka pengujian selanjutnya dilakukan pengubahan proporsi bandwidth tiap prioritas, didasarkan pada nilai bandwidth pengukuran saat ini. Jika pada pengujian terakhir dinyatakan H1 ditolak, maka disimpulkan bahwa perlu ada pendekatan lain untuk manajemen bandwidth.

\section{HASil dan PEMbahasan}

Pengambilan data trafik jaringan menggunakan Wireshark pada jam kerja pada pukul 08:00 hingga 16:00 WIB. Pengambilan data tersebut diambil di router utama Mikrotik Router RB750 jaringan LAN (Local Area Network) Kantor Kementerian Agama Kota Bogor. Teknik pengambilan data trafik menggunakan perangkat pada WinBox Packet Sniffing dengan memfilter udp port 37008 pada Wireshark karena port tersebut digunakan Winbox untuk me-capture trafik jaringan [10]. Data yang tersimpan dalam bentuk file berekstensi *.pcap.

Klasifikasi layanan dilakukan berdasarkan Tabel 1 dan dilakukan penghitungan statistik untuk mendapatkan nilai jumlah request, delay, jitter dan paket data. Hasil yang diperoleh ditunjukkan pada Tabel 4 untuk hasil pengujian 1 . Hasil tersebut menunjukkan bahwa penggunaan internet sebesar 60\% dari bandwidth keseluruhan (10000 kbps), dengan rincian layanan $e$ goverment (EMIS dan SIMBI) 8\%, pendukung layanan e-goverment (google service) 3\%, hiburan (Youtube dan Instagram) 49\%, dan tidak terklasifikasikan (etc) $0 \%$. Penggunaan internet pada studi kasus ini lebih banyak digunakan untuk mengakses layanan yang bersifat hiburan.

Hasil dari klasifikasi layanan pada pengujian 1 (Tabel 4) digunakan untuk penyesuaian bandwidth menggunakan fractional knapsack problem. Dasar penghitungan menggunakan Persamaan 2 dan 3 dengan nilai proporsi tiap prioritas pada Tabel 2 dan konsumsi bandwidth setiap layanan $\left(w_{i}\right)$ pada kolom terakhir Tabel 3. Nilai hasil klasifikasi layanan ditunjukkan dalam Tabel 5. Hasil penghitungan fractional knapsack problem tersebut berimplikasi bahwa alokasi bandwidth dapat dioptimalkan dari resource bandwidth yang ada. Jumlah bandwidth yang dialokasikan pada penghitungan tersebut adalah $5000.001 \mathrm{kbps}$.

Implementasi pembagian / alokasi bandwidth dilaksanakan pada bulan April hingga Juni 2018 di hari kerja mulai jam 08:00 sampai 16:00 WIB pada router utama di jaringan Kantor Kementerian Agama Kota Bogor. Alokasi menggunakan konfigurasi firewall filter dan mangle pada perintah CLI. Proses implementasi 
Tabel 4. Hasil klasifikasi layanan pengujian 1

\begin{tabular}{lccccc}
\hline Layanan & $\begin{array}{c}\text { Total } \\
\text { request (\%) }\end{array}$ & $\begin{array}{c}\text { Rataan } \\
\text { delay }(\mathbf{s})\end{array}$ & $\begin{array}{c}\text { Rataan } \\
\text { jitter }(\mathbf{s})\end{array}$ & $\begin{array}{c}\text { Rataan } \\
\text { throughput (kbps) }\end{array}$ & Paket data, $w_{j i}$ (kb) \\
\hline EMIS Pendis & 3 & 1.132 & 0.581 & 449.906 & 587.5 \\
SIMBI BIMAS Islam & 1 & 0.703 & 0.351 & 165.448 & 312.099 \\
Google service & 3 & 1.088 & 0.545 & 304.765 & 315.263 \\
Youtube & 92 & 0.402 & 0.201 & 4885.611 & 21903.133 \\
Instagram & 0 & 19.122 & 9.563 & 2.286 & 27.383 \\
Etc (Tidak terklasifikasikan) & 0 & 11.471 & 6.181 & 1.288 & 16.047 \\
\hline
\end{tabular}

Tabel 5. Hasil klasifikasi layanan menggunakan fractional knapsak problem di pengujian 1

\begin{tabular}{llcccc}
\hline $\boldsymbol{j}$ & Layanan ke-j & $\begin{array}{c}\text { Paket data } \\
(\mathbf{K b})\end{array}$ & $\begin{array}{c}\text { Value, } \\
v_{j i}\end{array}$ & $\begin{array}{c}\text { Proporsi bandwidth } \\
\text { tiap layanan, } r_{j i}\end{array}$ & $\begin{array}{c}\text { Alokasi bandwidth, } w_{j i} \\
(\mathbf{k b p s})\end{array}$ \\
\hline 1 & EMIS Pendis & 587.5 & 3 & 0.633 & 1899.846 \\
2 & SIMBI BIMAS Islam & 312.099 & 3 & 0.367 & 1100.154 \\
3 & Google service & 315.263 & 2 & 1.000 & 1500.000 \\
4 & Youtube & 21903.133 & 1 & 0.998 & 499.011 \\
5 & Instagram & 27.383 & 1 & 0.001 & 0.624 \\
6 & Etc (Tidak terklasifikasikan) & 16.047 & 1 & 0.001 & 0.366 \\
Jumlah & & & & 5000.001 \\
\hline
\end{tabular}

Tabel 6. Pengujian efektifitas bandwidth pengujian 2

\begin{tabular}{lcccccccc}
\hline \multirow{2}{*}{ Layanan } & \multicolumn{3}{c}{ Total request (\%) } & \multicolumn{2}{c}{ Delay (s) } & \multicolumn{2}{c}{ Jitter (s) } & \multicolumn{2}{c}{ Throughput (kbps) } \\
\cline { 2 - 9 } & $\mathbf{A}$ & $\mathbf{B}$ & $\mathbf{A}$ & $\mathbf{B}$ & $\mathbf{A}$ & $\mathbf{B}$ & $\mathbf{A}$ & $\mathbf{B}$ \\
\hline EMIS Pendis & 3 & 0 & 1.132 & 7.223 & 0.581 & 3.788 & 449.906 & 500.445 \\
SIMBI BIMAS Islam & 1 & 0 & 0.703 & 1.383 & 0.351 & 0.692 & 0.704 & 1129.622 \\
Google Service & 3 & 88 & 1.088 & 3.303 & 0.545 & 2.000 & 304.765 & 827.045 \\
Twitter & 0 & 0 & 0 & 3.003 & 0 & 1.611 & 0 & 2716.958 \\
Instagram & 0 & 0 & 19.123 & 47.132 & 9.563 & 23.574 & 2.286 & 5.212 \\
Youtube & 92 & 11 & 0.402 & 0.495 & 0.202 & 0.333 & 4885.611 & 641.932 \\
Game & 0 & 0 & 0 & 41.931 & 0 & 20.976 & 0 & 1.233 \\
Etc (Tidak terklasifikasikan) & 0 & 0 & 11.472 & 3.265 & 6.182 & 2.140 & 1.288 & 622.171 \\
\hline
\end{tabular}

dilakukan pengujian menggunakan t-hitung berpasangan dengan parameter uji nilai throughput, jitter, dan delay. Hasil penghitungan alokasi bandwidth pada pengujian 1 diimplementasikan untuk penyesuaian bandwidth pada pengujian 2. Hasil perbandingan klasifikasi layanan tersebut ditampilkan pada Tabel 6 . Kolom A menyatakan hasil sebelum dilakukan penyesuaian bandwidth, sedangkan kolom B menyatakan hasil setelah dilakukan penyesuaian bandwidth menggunakan fractional knapsack problem.

Untuk melihat tingkat signifikasi dari penyesuaian bandwidth dengan nilai perubahan prosentase total request, dilakukan uji statistik seperti ditunjukkan dalam Tabel 7. Nilai t-hitung throughput adalah sebesar 0.193 dan nilai derajat bebas $(v)$ sebesar 6. Distribusi $t$ 2-tail mendapatkan taraf signifikansi antara 50\% sampai 75\%. Nilai t-hitung jitter adalah sebesar -1.020 dan nilai derajat bebas $(v)$ sebesar 9. Distribusi $t$ 2-tail mendapatkan taraf signifikansi antara 80\% sampai 85\%. Nilai t-hitung delay adalah sebesar -0.994 dan nilai derajat bebas (v) sebesar 9. Distribusi $t$ 2-tail mendapatkan taraf signifikansi antara 80\% sampai 85\%. Ketiga parameter tersebut memiliki taraf signifikansi lebih dari $70 \%$ sehingga dapat dinyatakan bahwa
Tabel 7. Hasil pengujian keseluruhan

\begin{tabular}{lcc}
\hline Komponen & Pengujian 1 (\%) & Pengujian 2 (\%) \\
\hline Throughput & $50-75$ & $50-75$ \\
Jitter & $50-75$ & $80-85$ \\
Delay & $75-80$ & $80-85$ \\
\hline
\end{tabular}

metode yang digunakan dapat secara efektif digunakan untuk pembagian bandwidth. Namun, masih terdapat taraf signifikasi antara $50 \%$ dan $70 \%$ pada throughput. Hal ini disebabkan karena kapasitas dari bandwidth bersifat tetap sesuai dengan service level agreement (SLA) sehingga transfer rate atau transfer paket data rata-rata tidak melebihi nilai tersebut.

Kinerja manajemen bandwidth untuk setiap parameter uji throughput, jitter, dan delay ditunjukkan dalam Gambar 1-3. Nilai throughput mengalami perubahan yang besar (Gambar 1). Throughput pada pengujian ke-1 mengalami peningkatan karena pada hasil pengujian pada topologi 1 belum teridentifikasi layanan Youtube yang menunjukkan bahwa penggunaan jaringan internet pada Kantor Kementerian Agama Kota Bogor lebih banyak digunakan untuk layanan yang 
bersifat hiburan. Setelah dilakukan penghitungan ulang, nilai penyesuaian bandwidth terlihat pada pengujian ke2 di topologi 2 dan dapat menurunkan nilai throughput pada layanan berprioritas rendah, seperti Youtube dan game, serta dapat meningkatkan nilai throughput pada layanan berprioritas tinggi, yaitu layanan e-government (EMIS Pendis dan SIMBI BIMAS Islam). Manajemen bandwidth ini juga memberikan pertambahan yang signifikan ke nilai jitter (Gambar 2) dan delay (Gambar 3) terhadap layanan bersifat hiburan.

Manajemen alokasi bandwidth menggunakan fractional knapsak problem berhasil mengendalikan jumlah throughput, namun di sisi lain nilai delay dan jitter masih tinggi. Jika dibandingkan [5], pembagian bandwidth menggunakan model knapsack 0-1 dapat berjalan dengan baik, efektif, dan lebih stabil dalam pengendalian nilai delay karena prioritaskan untuk satu layanan saja dibandingkan dengan hasil penelitian ini yang multilayanan. Berbeda dengan [3] dan [4], penggunaan fractional knapsack problem untuk melayani lebih dari 1 layanan menghasilkan penurunan nilai delay dan jitter, jika nilai throughput dinaikkan, ketiga parameter tersebut saling berkaitan dalam proses transfer data. Ketiga parameter tersebut dapat berpengaruh terhadap manajemen bandwidth untuk meningkatkan kualitas QoS. Penambahan free space alokasi bandwidth masih perlu dilakukan untuk mendapatkan nilai optimum menggunakan model penghitungan statistik atau metode optimasi yang lain berdasarkan kondisi trafik jaringan sebelum penerapan manajemen ini.

\section{KESIMPULAN}

Metode fractional knapsak problem dapat secara efektif diterapkan dalam pembagian bandwidth setiap layanan berdasarkan tingkat prioritas layanan dengan nilai signifikansi tinggi, yaitu sebesar 75-85\%, untuk parameter uji throughput, jitter, dan delay. Pada pembagian bandwidth perlu diberikan nilai proporsi pada setiap prioritas dan layanan secara dinamis dengan menambahkan free space alokasi bandwidth untuk menurunkan nilai delay dan jittter.

\section{UCAPAN TERIMA KASIH}

Kantor Kementerian Agama Kota Bogor dan Direktorat Jenderal Pendidikan Islam Kementerian Agama Republik Indonesia yang telah membantu dan memfasilitasi pelaksanaan penelitian ini.

\section{DAfTAR Pustaka}

[1] Sekretaris Jenderal Kementerian Agama, "Surat Edaran Nomor SJ/B.VIII/2/HM.00/1558/2017 tentang Kebijakan Penggunaan Jaringan Internet dan Internet di Lingkungan Kementerian Agama,” Kementerian Agama Republik Indonesia, 2017.

[2] M. A. Shargabi, A. Shaikh, and A. S. Ismail, "Enhancing the Quality of Service for Real Time Traffic over Optical Burst Switching (OBS)

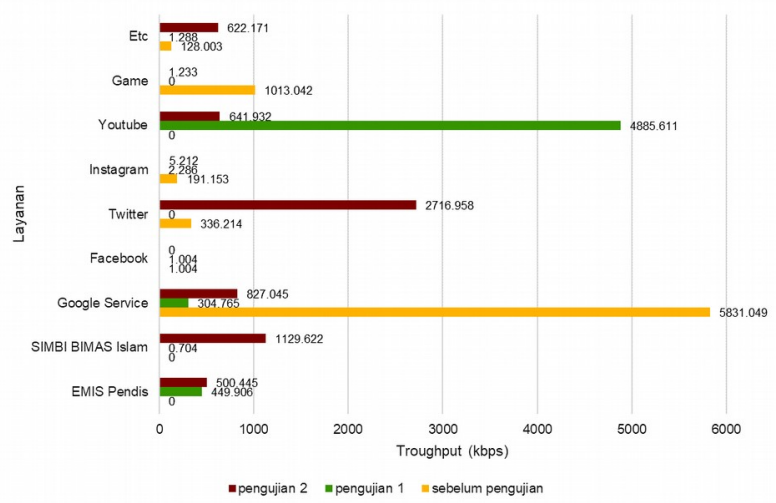

Gambar 1. Nilai throughput pada setiap pengujian

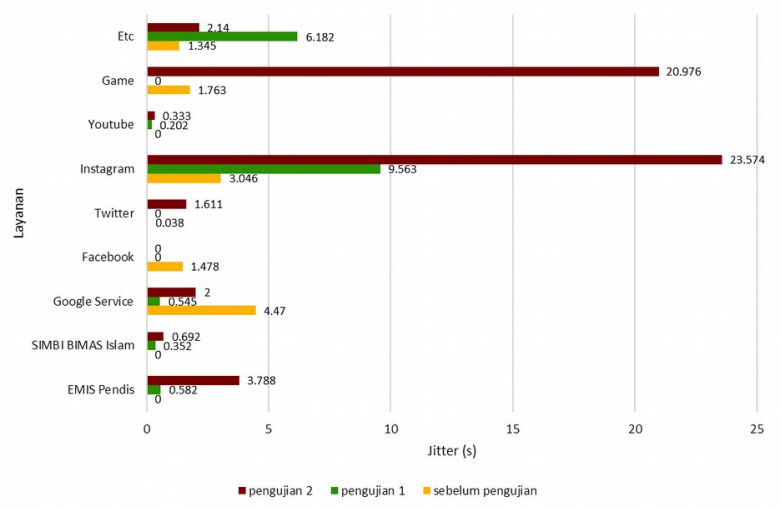

Gambar 2. Nilai jitter pada setiap pengujian

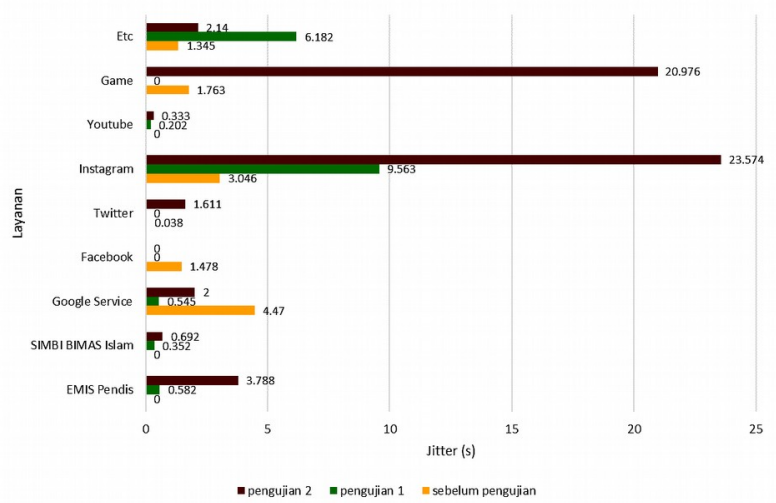

Gambar 3. Nilai delay pada setiap pengujian

Networks with Ensuring the Fairness for Other Traffics,” PloS One, vol. 11, no. 9, pp. 1-29, 2016.

[3] V. K. Singh, “Qos-based Techniques: Investigation and Optimization," International Journal of Engineering Science (IJEST), vol. 6, no. 5, pp. 5242-5246, 2016.

[4] N. Ferdosian, M. Othman, K. Y. Lun, and B. M. Ali, "Optimal Solution to the Fractional Knapsack Problem for LTE Overload-State Scheduling,” in 2016 IEEE 3rd International Symposium on Telecommunication Technologies (ISTT), Kuala Lumpur, Malaysia, Nov. 2016. 2016, pp. 97-102.

[5] X. W. Zhang and H. H. Dong, "A Bandwidth Allocation Strategy for Train-to-Ground 
Communication System of Urban Mass Transit,” Applied Mechanics and Materials, vol. 742, pp. 669-673, 2015.

[6] S. Martello and P. Toth, "Algorithms for Knapsack Problem," North-Holland Mathematics Studies, vol 132, pp. 213-257, 1987.

[7] B. Korte and J. Vygen, Combinatorial Optimization. Heidelberg: Springer-Verlag. 2018
[8] S. Supono, Modul MTCNA (Mikrotik Certified Network Associate). Jakarta: Inixindo, 2011.

[9] W. Navidi, Statistics for Engineers \& Scientists 4th Edition. New York: McGraw-Hill, 2014.

[10] P. Saxela and S. K. Sharma, "Analysis of Network Traffic by using Sniffing Tool: Wireshark," International Journal of Advance Research, Ideas and Innovations In Technology (IJARIIT), vol. 3, no. 6, pp. 804-808, 2017. 